$$
\begin{gathered}
\text { マイクロドロップレット試験を用いな } \\
\text { カーボン繊維強化而熱高分子基複合材料の界面強度評価 } \\
\text { 佐藤 光桜*1, 今井えりな*1, 小 柳 潤*2, 石田 雄一*3, 小笠原俊夫*4 } \\
\text { (2016 年 } 7 \text { 月 } 13 \text { 日受付 })
\end{gathered}
$$

\title{
Evaluation of Interfacial Strength of Carbon Fiber Reinforced Temperature Resistant Polymer Composites by Micro-Droplet Test
}

\author{
Mio Sato, ${ }^{* 1}$ Erina ImaI, ${ }^{* 1}$ Jun KoyanagI, ${ }^{* 2}$ Yuichi IshidA ${ }^{* 3}$ and \\ Toshio OGASAWARA*4
}

(Received July 13, 2016)

\begin{abstract}
This paper presents an evaluation method for the fiber/matrix interfacial strength. The interfacial strength is determined by comparing experimental data with numerical simulations. The micro-droplet test is conducted, and the fiber axial stress at the point of interface debonding is obtained. A numerical simulation is performed with ABAQUS using an axisymmetric finite element model. In the numerical simulation, an accurate value of the thermal residual stress based on the thermo-viscoelasticity and the damage to the resin around the blade-contacting point are considered to simulate the experimental phenomena ideally. In the thermal residual stress analysis, the actual thermal residual stress is calculated by considering the relaxation modulus and the timetemperature superposition principle for the resin. Damage initiation criteria for both dilatational and shear cases, based on continuum damage mechanics, is considered for the resin. Interfacial debonding is simulated by using a cohesive zone model, and the interfacial strength is determined as strength of the cohesive zone element when the fiber maximum stress by simulation corresponds to the experiments.
\end{abstract}

Key words: Interfacial strength, Continuum damage mechanics, Micro-droplet test, FEM, Cohesive zone model

\section{1. 緒}

\section{言}

ターボファンエンジンのインナーフレーム構造などの 従来のチタン材料部分に耐熱高分子基複合材料を適用す るべく，ポリイミド TriA-X を用いた耐熱複合材料が近 年開発された ${ }^{1,2)}$. 複合材料の機械特性の一つである繊 維/樹脂界面の機械的特性は複合材料の静的強度にはも

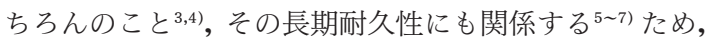

この正確な評価は必要不可欠である，著者らのこれまで の取り組みを含め ${ }^{8 \sim 10)}$, 様々な界面強度評価法が存在す る. 単繊維引き抜き試験 ${ }^{11 \sim 14)}$, 単繊維押し込み試験 ${ }^{15 \sim 18)}$, 単繊維押し出し試験 ${ }^{19 \sim 21)}$, フラグメンテーション試 験 $^{14,22,23)}$, マイクロドロップレット試験 ${ }^{12,14,24 ~ 27), ~ c r u c i-~}$ form 試験 ${ }^{28,29)}$ などが挙げられる. 中でもマイクロドロ ップレット試験と単繊維引き抜き試験は, 界面が周りの 樹脂より強い場合でも界面破壊を発生させることがあ

*1 東京理科大学大学院基礎工学研究科材料工学専攻 (125-8585 東京都葛飾区新宿 6-3-1)

Graduate School of Tokyo University of Science

*2 東京理科大学基礎工学部材料工学科

Department of Materials Science and Technology, Tokyo University of Science

*3 宇宙航空研究開発機構

Japan Aerospace Exploration Agency

*4 東京農工大学工学部機械システム工学科

Department of Mechanical Systems Engineering, Tokyo University of Agriculture and Technology 
り, 相対的に強い界面の強度測定にも適用できる場合が ある.このことは次報にて詳しく述べることとし, ここ では詳細は割愛する。本研究はマイクロドロップレット 試験 30 35) を適用する.マイクロドロップレット試験の研 究に関しては Nishikawa ら ${ }^{30)}$ が近年では最も本質的な 成果を発表しており，特筆に值する。ブレード接触付近 の樹脂破壊を初めて組み込んだ丁寧なモデリングがなさ れている。

界面強度を正確に評価するためには，まず界面を破壊 する実験を行い，その結果を境界条件とした数值解析を 行い, 界面に生じている応力を評価する手順が望まし い. 本研究では, 新しく以下の点において発展させた数 值解析を実施し，実験事実を忠実にシミュレートするこ とで界面強度を評価した。本解析ではまず任意の場所で の樹脂の損傷を考慮し，例元ば界面強度が極端に高い場 合, 樹脂損傷だけが進展して界面は破壞しないというシ ミュレーションを可能にした。次に, 熱粘弾性を考慮し た正確な熱応力を取り入れた。このことは本研究で用い るような耐熱高分子には必須事項であり，すなわち成形 温度が高い場合, 冷却途中に熱応力の一部は粘弾性応力 緩和により減少していることを考慮している. 本解析で は線形粘弾性構成則とアレイニウス型の温度-時間換算 則を用いた。近年界面破壊の数值解析では主流となりつ つある, 混合モード破壊条件を考慮した cohesive zone modeling (CZM) を用いて界面破壞をシミュレートした。

ここでCZM に関して一点注記したい.CZM を界面 破壞の数值シミュレーションに採用する際に, 現実離れ した極端な仮定が含まれていることがまれにある。例え ば結合力要素 (cohesive element) の力-分離則において, 分離定義の相対変位が炭素繊維半径の 10 倍である等, 物理的に合理的とみなせない值が設定されていることが ある。例えば DCB 試験のようにファイバーブリッジン グを再現している等のケースと異なり, 界面のはく離の 再現に「体積はないが繊維半径の 10 倍の距離まで結合 力が作用する界面要素を設定する」というのは, 著者ら は受け入れがたい。 また一方では，損傷以前における結 合力の相対変位に対する勾配が非常に小さく, 随分柔ら かい界面相が存在してそれが極端に変形しているケース 等もある。これらはすなわち実験と解析のある特定の物 理量を整合させるべく, CZM の定数の一部を都合よく 扱っていることが多い. 本解析では，実際の想定を逸脱 しすぎないよう考慮したいわゆる現実的な值を設定して 界面強度の評価解析を行った。

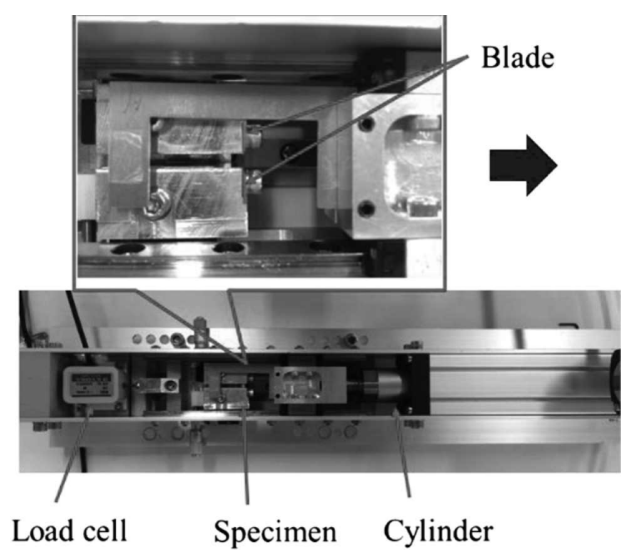

Fig. 1 Tensile testing machine.

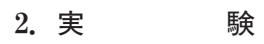

\section{1 万法}

炭素繊維（三菱レイヨン MR-50R）1本に溶媒を含む ポリイミド TriA-X 樹脂 (JAXA) を塗布し, 電気炉にて 硬化させた。室温から $50^{\circ} \mathrm{C}$ まで $2.5^{\circ} \mathrm{C} / \mathrm{min}$ で上昇, この まま 30 分保持, その後は $5^{\circ} \mathrm{C} / \mathrm{min}$ で $50^{\circ} \mathrm{C}$ 上昇させその 温度で 30 分保持する, という操作を $300^{\circ} \mathrm{C}$ まで繰り返し

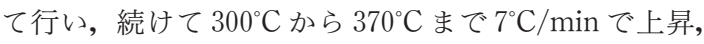
$370^{\circ} \mathrm{C}$ で 60 分保持し完全に硬化させ, しかる後 60 分か けて常温に冷却し, 供試体とした。

引張試験機（(株）白崎製作所）を用いて引張試験およ び観察を行った. 引張試験機を Fig. 1 に示す. Cylinder の先にコの字の試験片を取り付け, 樹脂玉を両側からブ レードで挟み, Fig. 1 の矢印の方向に荷重を負荷速度 6 $\mathrm{mm} / \mathrm{s}$ で与えた.このとき,ブレードは炭素繊維から $2 \pm$ $1 \mu \mathrm{m}$ 離れていた。樹脂玉が剥がれた際の界面にかかる 荷重を load cell で測定した。また, 樹脂玉が䋊維から剥 がれる様子は光学顕微鏡下で観察し, 樹脂玉の寸法は光 学顕微鏡のスケールを用いて測定した。

\section{2 実 験 結 果}

Fig. 2 にマイクロドロップレット試験前後の供試体の 光学顕微鏡写真 $(\mathrm{a} \sim \mathrm{c})$ および荷重-時間図 $(\mathrm{d})$ を示す. 試験で対象とした樹脂玉は丸で囲ったものである. 樹脂 玉の寸法は長径が $43 \mu \mathrm{m}$, 短径が $25 \mu \mathrm{m}$ であった. Fig. 2 (a), (b)の丸で囲った樹脂玉に着目すると, 試験前と試 験後では炭素繊維に付着していた樹脂玉の位置が異なっ ており, 試験が狙い通り行われていることが確認できる. また，(c)の写真に着目すると，樹脂玉がわずかに損傷し ていることがわかる. Fig. 2(d) に示されるピークが炭素 


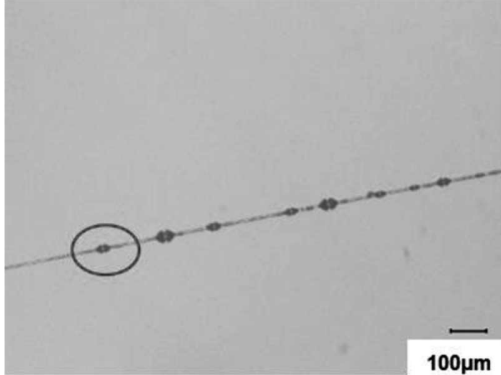

(a)

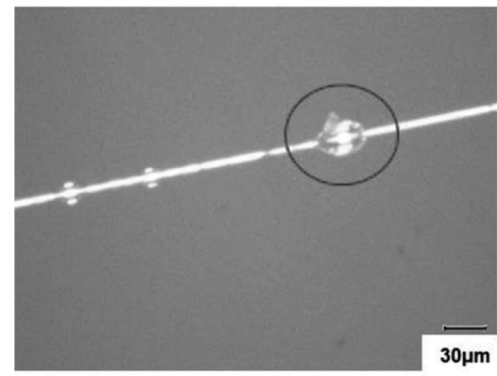

(c)

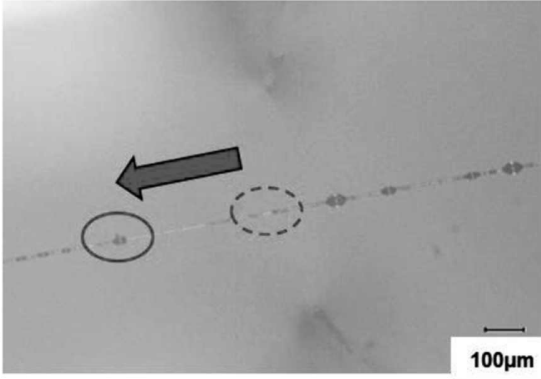

(b)

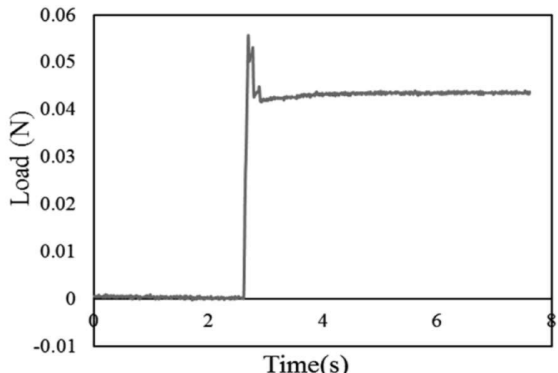

(d)

Fig. 2 Optical microscope image of micro-droplet experiment and the result. (a) Before experiment. (b) After experiment. (c) Magnified view of (b). (d) Relationship between load and time during test.

繊維から樹脂玉が剥がれた瞬間を示しており，その荷重 は $0.056 \mathrm{~N}$ であった. ピーク後も荷重が残っているのは 次の障害物に当たって樹脂玉の移動が妨げられたことに よるものである。この実験で得られたピーク時の繊維荷 重を数值解析の境界条件とし, 実験と解析を比較するこ とで繊維/樹脂間の界面強度を求める。

\section{3. 解 析}

\section{1 解析モデル概要}

Fig. 2 の写真を基に，以下の Fig. 3 に示す軸対称モデ ルを作成した。繊維半径は $3 \mu \mathrm{m}$, 樹脂玉長径は $43 \mu \mathrm{m}$, 短径は $25 \mu \mathrm{m}$ とした. 本数值解析には汎用有限要素解 析ソフトABAQUS 6.14 を使用する. 六節点軸対称二次 要素を用い, 節点数は約 3,200 , 要素数は約 1,500 である. モデルの繊維，樹脂，ブレードに設定した材料特性を以 下の Table 1 に示す.ここで, 計算コスト削減のためブ レードは実寸より小さいモデルを用いたため，実際より 高い弾性率を設定してブレードの変形量を少なくした。 樹脂と繊維の間には結合力要素を導入した。ブレードは 本来軸対称ではないが，軸対称モデルと三次元モデルで 界面に作用する最大応力の值は大きく異ならないこと淿 を注記しておく.また, 実験上のブレードの先端形状は,

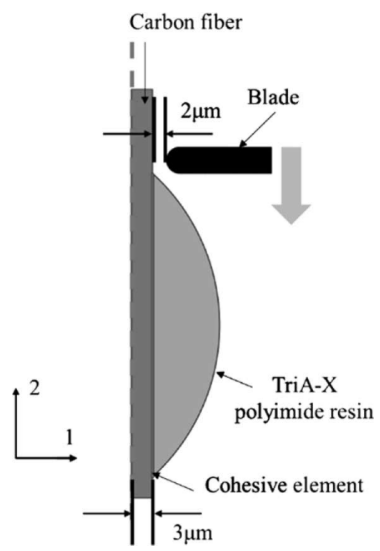

Fig. 3 Axisymmetric model.

微視的に観察すると鋭利なものではないため, 解析モデ ルでは先端を丸めた形状に設計した. 本解析では樹脂に おいて, 正確な熱応力の評価には粘弾性を, 界面はく離 シミュレーション時には弾塑性と連続体損傷力学を考慮 する.これらの詳細については後述することとし, Table 1 にはその弾性成分のみ記す。

ここでは結合力要素について述べる. 用いる結合力要 素は混合モードを考慮した 2 直線の力-分離則が定義さ 
Table 1 Mechanical properties. ${ }^{30)}$

\begin{tabular}{lcc}
\hline \hline Fiber axial modulus & $E_{2}$ & $294 \mathrm{GPa}$ \\
Fiber transverse modulus & $E_{1}, E_{3}$ & $14 \mathrm{GPa}$ \\
Fiber axial Poisson's ratio & $N_{12}$ & 0.02 \\
Fiber transverse Poisson's ratio & $N_{13}$ & 0.3 \\
Fiber transverse Poisson's ratio & $N_{23}$ & 0.35 \\
Fiber axial shear modulus & $G_{12}, G_{23}$ & $18 \mathrm{GPa}$ \\
Fiber transverse shear modulus & $G_{13}$ & $5 \mathrm{GPa}$ \\
Fiber axial thermal expansion coefficient & $\alpha_{22}$ & $1 \times 10^{-6}\left(\mathrm{~K}^{-1}\right)$ \\
Fiber transverse thermal expansion coefficient & $\alpha_{11}, \alpha_{33}$ & $1 \times 10^{-5}\left(\mathrm{~K}^{-1}\right)$ \\
Matrix modulus & - & $3 \mathrm{GPa}$ \\
Matrix Poisson's ratio & - & 0.34 \\
Matrix thermal expansion coefficient & - & $2.5 \times 10^{-5}\left(\mathrm{~K}^{-1}\right)$ \\
The blade modulus & - & $1 \times 10^{5} \mathrm{GPa}^{-}$ \\
\hline
\end{tabular}

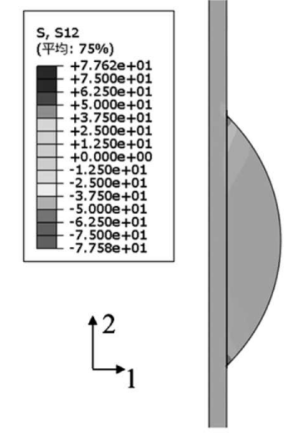

(a) Viscoelastic resin

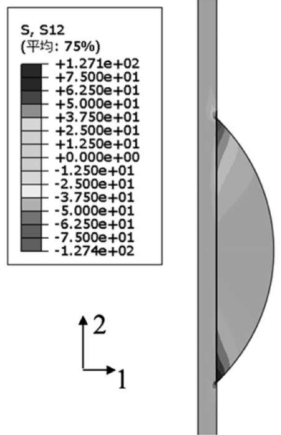

(b) Elastic resin

Fig. 4 Numerical results for S12 stress distribution.

れている10).ただし本研究では純粋せん断強度と純粋引 つ張り強度，ならびにそれらの破壊じん性值はそれぞれ 同一とした。つまりモード I とモード II で強度・じん性 を同じ值とした。本研究では接点力が消失するときの接 点の相対変位（すなわち完全分離を定義する変位）を 0.3 $\mu \mathrm{m}$ で固定した ${ }^{8)}$. 従って, 結合力要素の最大応力を変化 させると，これに伴ってじん性も線形に変化する。結合 力要素の最大応力を変化させて, 界面はく離時の繊維応 力が実験と整合することを狙って解析を繰り返し実施す る.

\section{2 熱応力解析}

本試験片は $370^{\circ} \mathrm{C}$ で硬化させるため, 常温との温度差 は大きく，これに付随して発生する熱応力は無視できな い值であると考えられる。一方で，線膨張係数差と温度 差からなる線形弾性 FEM による熱応力は值が大きす ぎ，場合によっては熱応力で界面が破壊するという結末 にもなりかねない. しかし実際には樹脂の粘弾性特性に より界面の熱応力は時間とともに緩和し, これは特に温
度が高いときは緩和速度も速いため, 線形弾性 FEM で 得られる值よりは熱応力は小さくなっているはずであ る. 本研究では, 樹脂のみのクーポン試験片を用いて応 力緩和試験を行い, 下式に示される緩和弾性率を求め た た $^{36)}$

$$
E(t)=\frac{E_{0}}{\left(1+\left(\frac{t}{\tau_{\mathrm{c}}}\right)^{n}\right)}
$$

ここで， $E_{0}$ は初期弾性率， $\tau_{\mathrm{c}}$ は緩和時間， $n$ はべき乗則 である。応力緩和試験より得られた各定数はそれぞれ， $\tau_{\mathrm{c}}=1.0 \times 10^{7} \mathrm{~s}, n=0.34$ であった. 試験とパラメータフィ ッティングの詳細は本論文では割愛する。

次に温度が高いと緩和時間が短くなる（応力緩和が速 くなる）ことを記述するために，本研究では下記のアレ イニウス型の温度時間換算則を適用する ${ }^{36)}$.

$$
\log \alpha=\frac{\Delta H}{2.303 R}\left(\frac{1}{T}-\frac{1}{T_{\mathrm{R}}}\right)
$$




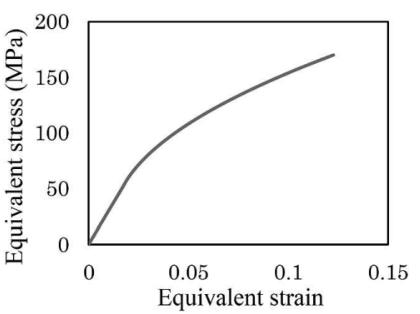

(a)

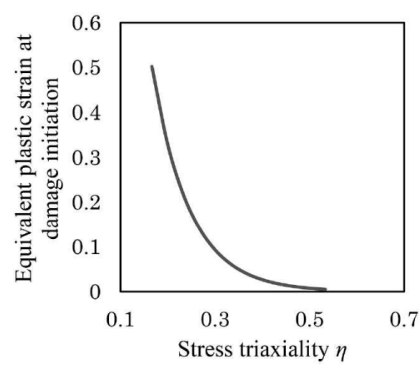

(b)

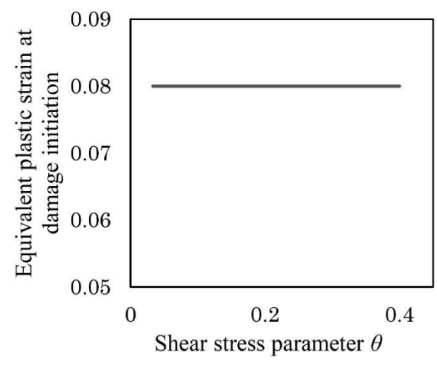

(c)

Fig. 5 The constitutive law for resin and the damage initiation criteria. (a) Constitutive law at uniaxial loading. (b) Hydrostatic pressure damage initiation criterion. (c) Shear damage initiation criterion.

$\alpha$ は時間の加速率， $\Delta H$ は活性化エネルギー, $R$ は気体 定数, $T_{\mathrm{R}}$ は参照温度, $T$ は現在の温度である. 動的粘弾 性（DMA）試験を樹脂のクーポン試験片に対して実施 し, マスターカーブを作成し, 続いて上式に従ってアレ イニウスプロットを作成し，その傾きから活性化エネル ギー $\Delta H=160 \mathrm{~kJ} / \mathrm{mol} \cdot \mathrm{K}$ を得た。時間の加速率 $\alpha$ は次 式にて換算されこれを(4)式の履歴を考慮した応力ひず み関係式に代入することで, 温度履歴を考慮した試験片 の熱残留応力を求めることができる.ここで， $(t)$ は換 算時間, $T$ は温度, $\tau(t)$ はせん断応力, $E$ は緩和弾性率

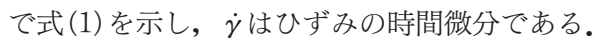

$$
\begin{gathered}
\xi(t)=\int_{0}^{t} \frac{d s}{\alpha(T(s))} \\
\tau(t)=\int_{0}^{t} E(\xi(t)-\xi(s)) \dot{\gamma}(s) d s
\end{gathered}
$$

本研究では， $370^{\circ} \mathrm{C}$ に熱した試験片を室温 $\left(30^{\circ} \mathrm{C}\right)$ まで $3,600 \mathrm{~s}$ で冷却したと仮定し，上記の熱粘弾性を考慮した 熱応力解析を行った. Fig. 4 亿樹脂に熱粘弾性を考慮し た場合と弾性を仮定した場合のS12 の応力分布を示す. 熱粘弾性を考慮することで熱応力が約 $50 \mathrm{MPa}$ (約 4 割) 緩和されて減少しており，樹脂の熱粘弾性を考慮するこ とが重要であることがわかる，この樹脂の熱応力がその 付近の界面の熱応力と等価であることを注記しておく.

\section{3 損 傷 解 析 ${ }^{37)}$}

界面強度が相対的に高い場合, ブレードが樹脂に当た ったときに樹脂が局所的に損傷するか，もしくは界面が はく離せず樹脂のみが破壊することが想定される。本研 究では樹脂の損傷を考慮することで，より現実的なモデ リングを狙う。樹脂は弾塑性体と考えて Fig. 5(a)のよ うな応力ーひずみ関係を設定した。樹脂のみのクーポン 試験片を用いて引つ張り試験を行い，これを参考にして 応力ひずみ関係を図のように設定した。損傷の発生は相
当塑性ひずみの值を用いて定義する. 本研究では 2 種類 の損傷を考慮する。一つは静水圧応力によるボイド発生 に起因するもの (Fig. 5(b))，もう一つはせん断応力によ る損傷の発生（Fig. 5 (c)) である. 静水圧応力による損 傷発生基準は応力三軸度 ( (5) 式) の関数として, せん断 損傷発生基準はせん断応力パラメー夕（(6)式）の関数と して定義する。

$$
\begin{aligned}
& \eta=\frac{\sigma_{\mathrm{m}}}{\sigma_{\mathrm{eq}}} \\
& \theta=\frac{\sigma_{\mathrm{eq}}}{\tau_{\mathrm{max}}}
\end{aligned}
$$

ここで，(5) 式の $\sigma_{\mathrm{m}}$ は静水圧応力， $\sigma_{\mathrm{eq}}$ は相当応力，(6) 式の $\tau_{\max }$ は最大せん断応力である.

損傷発生基準を満たすと，損傷はその変数を $d$ とし式 (7) に従って発展する.ここで， $\bar{\varepsilon}_{\mathrm{f}}^{\mathrm{p}}$ は $d=1$ まで発展し たときの相当塑性ひずみである。損傷は $(1-d)$ を応力 に積することで表現される。損傷の完了(すなわち $d=1$ ) は式(8)に従って，エネルギー基準(材料の破壞エネルギ 一に相当する) で最終破壞時の相当ひずみ $\bar{\varepsilon}_{\mathrm{f}}$ が定義され る.

$$
\begin{gathered}
\dot{d}=\frac{\dot{\bar{\varepsilon}}_{\mathrm{f}}^{\mathrm{pl}}}{\bar{\varepsilon}_{\mathrm{f}}^{\mathrm{pl}}} \\
G_{\mathrm{f}}=\frac{\left(\bar{\varepsilon}_{\mathrm{f}}-\bar{\varepsilon}_{\text {ini }}\right) \sigma_{y 0}}{2}
\end{gathered}
$$

ここで， $\bar{\varepsilon}_{\mathrm{ini}} ， \sigma_{y_{0}}$ はそれぞれ破壊基準に達したときの相 当ひずみ, 相当応力である. 本研究では, 破壊エネルギ 一 $G_{\mathrm{f}}$ を $1 \mathrm{~N} / \mathrm{mm}^{2}$ として解析を行った。

\section{4 結果と考察}

解析経過を以下の Fig. 6 亿示す. コンターは S12 の応 力分布を示す.

ブレードが樹脂に当たり (a)，樹脂の損傷が界面に向 かうように進展し(b), 界面に挿入した結合力要素が破 


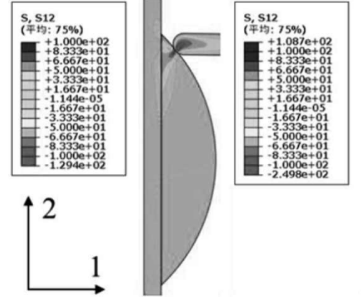

(a)

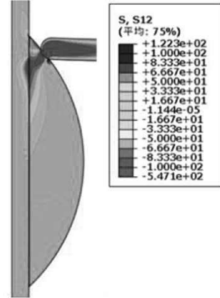

(b)

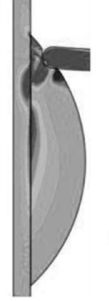

(c)

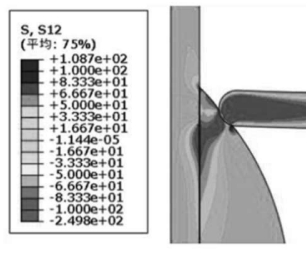

(d)

Fig. 6 Numerical results for S12 stress distribution. (a) The resin damage occurs around edge-contacting point with shear mode. (b) The crack grows toward the interface. (c) After progressive debonding. (d) Magnified view of (b).

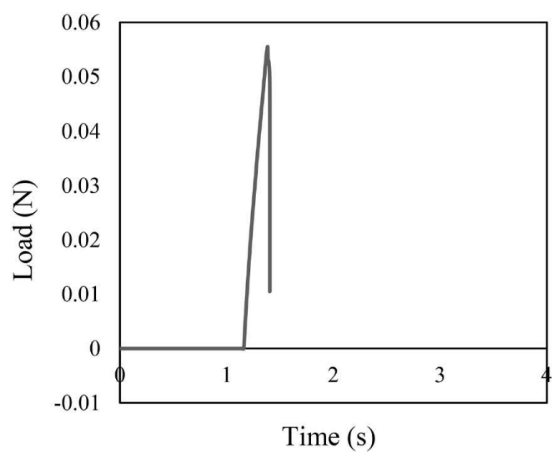

Fig. 7 Relationship between load and time during analysis.

壞されると界面のはく離が進展した(c). (d) は(b)の拡大 図で，損傷が $45^{\circ}$ 方向に進展していることを示している. この損傷が進展し, 界面に至り, しかる後結合力要素の 破壊に遷移して界面はく離がシミュレートされている。

解析上の纎維応力を実験值と比較し, 繊維応力が実験 值と近い值となるように結合力要素の強度を $5 \mathrm{MPa}$ ご とに変化させ，最も近い值となったときの結合力要素の 強度を界面強度とした。 その結果を以下の Fig. 7 に示 す. Fig. 7 の解析值は結合力要素の強度を $130 \mathrm{MPa}$ と設 定したときの荷重-時間図である.これより, Fig. 2(d) と 比較すると瀻維荷重のピークは実験值と解析值で良い一 致を示し, Fig. 1 で着目した樹脂玉の界面強度は 130 MPaであることがわかった。なお，極端に強い界面強度 設定して解析を実施する場合, 界面がはく離せず樹脂内 の破壞が伝播して，樹脂玉が破壞し，繊維荷重はなくな る。これは界面強度が高い場合はマイクロドロップ試験 では界面をはく離させることができないことを意味して おり，現実的なシミュレーションが実施できていると考 えられる。

また, 参考として見かけの界面強度（繊維荷重をはく
離面積で除した值：式(9)）と比較する.

$$
\tau_{\mathrm{app}}=\frac{F_{\max }}{\pi d_{\mathrm{f}} L_{\mathrm{em}}}
$$

ここで， $\tau_{\mathrm{app}}$ は見かけの界面強度， $F_{\max }$ はピーク荷重, $d_{\mathrm{f}}$ は纎維直径, $L_{\mathrm{em}}$ は樹脂玉長径である. 式(9)を用いて 算出された見かけの界面強度は $69 \mathrm{MPa}$ であった。これ より, 解析で得られた界面強度は式(9)で得られる值よ り高いことがわかる. 実際はブレード付近の界面応力が 高く, そこからはく離が発生・進展するが, このときの 界面全体のせん断応力の平均值が $69 \mathrm{MPa}$ ということを 意味し, 式(9)で得られる值を盲信することの危険性を 示している.さらに述べれば実際は熱応力の考慮もすべ きであるし，場合によっては本研究のように樹脂の損傷 も考慮すべきである.

\section{4. 結論}

本研究では, 繊維/樹脂間の界面強度を正確に評価する ために, 界面を破壞する実験抢よびその結果を境界条件 とした数值解析を行った。実験はマイクロドロップレッ 卜試験を適用し，纎維/樹脂間の界面がはく離した際の 繊維荷重を取得した。数值解析では, 樹脂の熱粘弾性を 考慮した正確な熱応力，任意の場所での樹脂の損傷を取 り入れた。界面破壊は混合モード破壞条件を考慮した CZM を用いてシミュレートした. 解析上の繊維応力と 実験值を比較し，それらが一致したときの結合力要素の 強度を界面強度とした。本研究で着目した繊維/樹脂間 の界面強度は数值解析の結果より, $130 \mathrm{MPa}$ であること がわかった。

本研究は戦略的イノベーション創造プログラム (SIP) 革新的構造材料の助成を受けて遂行された。ここに謝意 を表す。 


\section{参 考 文 献}

1) M. Miyauchi, Y. Ishida, T. Ogasawara \& R. Yokota: Polymer Journal, 44 (2012), 959-965.

2) M. Miyauchi, Y. Ishida, T. Ogasawara \& R. Yokota: Polymer Journal, 45 (2013), 594-600.

3) J. Koyanagi, M. Kotani, H. Hatta \&, H. Kawada : J. Compos. Mater., 43 (2009), 1901-1914.

4) J. Koyanagi, Y. Sato, T. Sasayama, T. Okabe \& S. Yoneyama : Composites Part A, 56 (2014), 136142.

5) J. Koyanagi, S. Yoneyama, K. Eri \& P.D. Shah : Compos. Struct., 92 (2010), 150-154.

6) J. Koyanagi, F. Ogawa, H. Kawada \& H. Hatta : J. Compos. Mater., 41 (2007), 3007-3026.

7) J. Koyanagi, G. Kiyota, T. Kamiya \& H. Kawada : Adv. Compos. Mater., 13, 3-4 (2004), 199-213.

8) J. Koyanagi, S. Ogihara, H. Nakatani, T. Okabe \& S. Yoneyama: Adv. Compos. Mater., 23 (2014), 551-570.

9) J. Koyanagi, H. Nakatani \& S. Ogihara : Composites Part A, 43 (2012), 1819-1827.

10) J. Koyanagi, P.D. Shah, S. Kimura, S.K. Ha \& H. Kawada : J. Solid Mech. Mater. Eng., 3 (2009), 796-806.

11) L.J. Broutman: Interfaces in Composites, ASTM STP 452 (1969), pp. 27-41.

12) L. Yang \& J.L. Thomason : Composites Part A, 41 (2010), 1077-1083.

13) T. Tsuda, T. Ogasawara, F Deng \& N. Takeda : Compos. Sci. Technol., 71 (2011), 1295-1300.

14) N. Graupner, J. Grossler, G. Ziegmann \& J. Mussig : Composites Part A, 63 (2014), 133-148.

15) J.F. Mandell, J.H. Chen \& F.J. McGarry : Int. J. Adhes. Adhes., 1 (1980), 40-44.

16) D.B. Marshall \& W.C. Oliver:J. Am. Ceram. Soc., 70, 8 (1987), 542-548.

17) M. Rodriguez, J. Molina-Aldareguía, C. González \& J. LLorca : Compos. Sci. Technol., 72, 15 (2012), 1924-1932.

18) C. Medina, J. Molina-Aldareguía, C. González, M. Melendrez, P. Flores \& J. LLorca : J. Compos. Mater., 50, 12 (2016), 1651-1659.
19) D.K. Shetty : J. Am. Ceram. Soc., 71, 2 (1988), 107-109.

20) M. Rollin, S. Jouannigot, J. Lamon \& R. Pailler : Compos. Sci. Technol., 69 (2009), 1442-1446.

21) A. Godara, L. Gorbatikh, G. Kalinka, A. Warrier, O. Rochez, L. Mezzo, F. Luizi, A.W. van Vuure, S. V. Lomov \& I. Verpoest: Compos. Sci. Technol., 70 (2010), 1346-1352.

22) A. Kelly \& W.R. Tyson : J. Mech. Phys. Solids, 13 (1965), 329-350.

23) A. Awal, G. Cescutti, S.B. Ghosh \& J. Müssig : Compositeis Part A, 42, 1 (2011), 50-56.

24) B. Miller, P. Muri \& L. Rebenfeld: Compos. Sci. Technol., 28, 1 (1987), 17-32.

25) X. Gao, R. Jensen, W. Li, J. Deitzel, S.H. McKnight \& J. Gillespie : J. Compos. Mater., 42, 5 (2008), 513-534.

26) X. Gao, R.E. Jensen, S.H. McKnight \& J.W. Gillespie Jr. : Composites Part A, 42, 11 (2011), 1738-1747.

27) L. Yang, J.L. Thomason \& W.Z. Zhu : Composites Part A, 42, 10 (2011), 1293-1300.

28) S. Ogihara \& J. Koyanagi : Compos. Sci. Technol., 70 (2010), 143-150.

29) S. Ogihara, Y. Sakamoto \& J. Koyanagi : J. Solid Mech. Mater. Eng., 3 (2009), 1071-1080.

30) M. Nishikawa, T. Okabe, K. Hemmi \& N. Takeda : Int. J. Solids Struct., 45, 14-15 (2008), 40984113.

31) S. Kang, D. Lee \& N. Choi : Compos. Sci. Technol., 69, 2 (2009) , 245-251.

32) Z. Liu, X. Yuan, A.J. Beck \& F.R. Jones : Compos. Sci. Technol., 71, 13 (2011), 1529-1534.

33) G. Pandey, C.H. Kareliya \& R.P. Singh :J. Compos. Mater., 46, 3 (2012), 275-284.

34) M.A. Minnicino \& M.H Santare: Compos. Sci. Technol., 72, 16 (2012), 2024-2031.

35) S. Sockalingam, M. Dey, J.W. Gillespie \& M. Keefe: Composites Part A, 56 (2014), 239-247.

36) J. Koyanagi, S. Yoneyama, A. Nemoto \& J.D.D. Melo: Compos. Sci. Technol., 70 (2010), 13951400 .

37) Abaqus Analysis User's Manual. 